\title{
Seed treatment for management of Meloidogyne javanica in soybean
}

\section{Tratamento de sementes para o manejo de Meloidogyne javanica em soja}

\author{
Adriely Alves de Almeida'; Vinicius Hicaro Frederico Abe ${ }^{2}$; Ricardo Marcelo \\ Gonçalves $^{3}$; Maria Isabel Balbi-Peña ${ }^{4}$; Débora Cristina Santiago ${ }^{5^{*}}$
}

\begin{abstract}
The objective of this study was to evaluate the efficacy of the active ingredient abamectin, either in isolation or in combination with fungicides and insecticides formulated for the industrial seed treatment, on the population of Meloidogyne javanica, tested under greenhouse and in vitro conditions. In both tests, the combination of the following treatments was assessed: abamectin; thiamethoxam; fludioxonil + metalaxyl-M + thiabendazole. Water was used as control for the in vitro assay, whereas under greenhouse conditions, controls were inoculated and not inoculated with $M$. javanica. The tests were conducted in a completely randomized design with six (in vitro) and ten (greenhouse) replicates. For in vitro studies the effect on hatching, motility, and mortality of juveniles of $M$. javanica was evaluated. Under greenhouse conditions, the soybean 'BRS 133' seeds were treated, and at 15, 30, and 60 days after inoculation (DAI) with M. javanica, plant measurements were recorded. The penetration of second stage juveniles (J2) was also evaluated at 15 DAI. At 30 DAI, galls, egg masses, nematodes/g of root, and final population were evaluated. At $60 \mathrm{DAI}$, the final population of nematodes in the roots was quantified. The treatments containing abamectin were the most effective in diminishing the hatching of juveniles. All treatments had an effect on nematode motility when compared to the control, and in the treatment containing only abamectin, total juvenile mortality was observed. In greenhouse conditions, at $15 \mathrm{DAI}$, the treated soybean plants had the highest root mass and shoot length, differing statistically from the inoculated control. All treatments reduced the number of nematodes per gram of root, differing from the control. At $30 \mathrm{DAI}$, treatment efficiency was observed in reducing the final population of $M$. javanica, particularly the treatments using abamectin, and abamectin + thiamethoxam + fludioxonil + metalaxyl-M + thiabendazole. However, at $60 \mathrm{DAI}$, the effect of the treatments on the population of $M$. javanica did not persist.
\end{abstract}

Key words: Hatching. Mortality. Motility. Nematicide. Root-knot nematode.

\section{Resumo}

O objetivo do trabalho foi avaliar a eficiência do ingrediente ativo abamectina, isolado ou em combinação com fungicidas e inseticidas formulados para o tratamento industrial de sementes, sobre a população de Meloidogyne javanica, in vitro e em casa de vegetação. Em ambos os ensaios, avaliou-se a combinação dos tratamentos: abamectina; thiamethoxam; fludioxonil + metalaxil-m + tiabendazol. Como controle utilizou-se água para o ensaio in vitro, e testemunhas inoculada e não inoculada com $M$. javanica, em casa de vegetação. Os ensaios foram realizados em delineamento inteiramente casualizado

\footnotetext{
${ }^{1}$ Discente de Doutorado, Programa de Pós-Graduação em Agronomia, Universidade Estadual de Londrina, UEL, Londrina, PR, Brasil. E-mail: adrielyalvesa@yahoo.com.br

${ }^{2}$ Eng $^{\mathrm{o}} \mathrm{Agr}^{\mathrm{o}}$, M.e, Alltech Crop Science, Londrina, PR, Brasil. E-mail: viniciushfabe@hotmail.com

${ }^{3}$ Pós-Doutorando, Programa de Pós-Graduação em Agronomia, UEL, Londrina, PR, Brasil. E-mail: goncalves.agrouel@gmail.com

${ }^{4}$ Prof $^{a}$ Dr $^{\mathrm{a}}$, Fitopatologia, Departamento de Agronomia, UEL, Londrina, PR, Brasil. E-mail: mariabalbi@uel.br

5 Prof ${ }^{a}$ Dr $^{\mathrm{a}}$, Fitopatologia/Nematologia, Departamento de Agronomia, UEL, Londrina, PR, Brasil. E-mail: santiago@uel.br

* Author for correspondence
} 
com seis (in vitro) e 10 (casa de vegetação) repetições. In vitro, avaliou-se o efeito sobre a eclosão, motilidade e mortalidade dos juvenis de $M$. javanica. Em casa de vegetação, as sementes da cultivar de soja BRS 133 foram tratadas e aos 15, 30 e 60 dias após a inoculação (DAI) com M. javanica foram realizadas mensurações fitométricas das plantas. Avaliaram-se, também, aos 15 DAI a penetração de juvenis de segundo estádio (J2); aos 30 DAI avaliou-se galhas, massas de ovos, nematoides/g de raiz e população final; e aos 60 DAI quantificou-se a população final de nematoides nas raízes. Os tratamentos contendo abamectina foram os mais eficientes em diminuir a eclosão dos juvenis. Todos os tratamentos apresentaram efeito na motilidade dos nematoides com relação à testemunha, sendo que no tratamento contendo apenas abamectina foi observada, também, a total mortalidade dos juvenis. Em casa de vegetação, aos 15 DAI, as plantas de soja tratadas apresentaram maior massa fresca de raiz e comprimento da parte aérea, diferindo estatisticamente da testemunha inoculada. Todos os tratamentos reduziram o número de nematoides por grama de raiz, diferindo da testemunha. Aos $30 \mathrm{DAI}$, observouse eficiência dos tratamentos em reduzir a população final de $M$. javanica, destacando-se os tratamentos abamectina e abamectina + thiamethoxam + fludioxonil + metalaxil-m + tiabendazole. No entanto, aos 60 DAI o efeito dos tratamentos não se manteve sobre a população de $M$. javanica.

Palavras-chave: Eclosão. Mortalidade. Motilidade. Nematicida. Nematoide de galhas.

\section{Introduction}

Soybean (Glycine max (L.) Merrill) is one of the most commercially significant crops in Brazil, and is the second-most produced commodity in the country, next only to sugarcane (FAO, 2016). Production in 2016/17 was 113.9 million tons, with the largest producers being the states of Mato Grosso, Paraná, Rio Grande do Sul, and Goiás (CONAB, 2017).

The wide geographic distribution, easy dissemination, and interaction with other soil pathogens place the phytonematodes among the main organisms responsible for damage to the soybean crop worldwide. In Brazil, the nematodes that are most damaging to soybean impacting yield are: Heterodera glycines Ichinohe, Pratylenchus brachyurus (Godfrey) Filipjev \& S. Stekhoven, Rotylenchulus reniformis Linford \& Oliveira, Meloidogyne incognita (Kofoid \& White) Chitwood and M. javanica (Treub) Chitwood. The genus Meloidogyne comprises a polyphagous group of highly adaptive, obligatory plant parasites widely distributed among agricultural crops. Typically, they reproduce and feed within the host cells, where they induce the formation of galls and cause characteristic symptoms in the aerial parts, such as poor growth and development, low vigor, and wilt, as a consequence of the damage caused to the root system (MOENS et al., 2010).
One of the control methods adopted most by growers is chemical control, the application of nematicides in the planting-furrow, as granulated or liquid formulations that guarantees productivity by reducing the damage caused by the phytonematodes in the roots (INOMOTO; ASMUS, 2006). However, these formulations could be highly toxic to the environment (KUBO et al., 2012), and they should be used moderately. To overcome the environmental impact caused by nematicides, while retaining its ability to control nematodes, seed treatment may be an option for the management of nematodes in different cropping systems (STARR et al., 2007). Nematicidal formulations based on the active ingredient abamectin (avermectins) have been developed specifically for seed applications. The efficiency of abamectin was first reported in the control of $M$. incognita in cotton (MONFORT et al., 2006), tomato (FASKE; STARR, 2007), and melon (MOREIRA et al., 2004); when applied at relatively low doses in the seed treatment, the active ingredient interacts with the tegument and interferes with the nematode population around it (FASKE; STARR, 2007; BESSI et al., 2010; CORTE et al., 2014). Other studies, however, indicate that seed treatment with nematicides offers good prospects when integrated with other measures within phytonematode management (FAVORETTO et al., 2010; STEFFEN et al., 2011). However, the main abamectin-based nematicide available in the market 
today is not directly sold to the producer, but only as an industrial seed treatment (IST). With the advent of IST using various products, and consequent addition of fungicides and/or insecticides, there is a demand on the part of farmers and technicians to know the possible effects of the interaction of these products on nematodes.

In this context, the objective of this study was to evaluate the effects of abamectin, isolated or in combination with thiamethoxam, fludioxonil, metalaxyl-M and thiabendazole, in the control of $M$. javanica, both in vitro and under greenhouse conditions.

\section{Material and Methods}

\section{Chemicals}

The experiments were conducted in laboratory (in vitro) and greenhouse conditions at the State
University of Londrina, PR, Brazil, in a completely randomized design with six replicates for the in vitro tests and 10 replicates for the greenhouse tests. Four active ingredients (products) used for soybean cultivation in Brazil were applied either in isolation or in combination. The treatments were: abamectin (Aba); thiamethoxam (Thiam); fludioxonil+metalaxyl-M+thiabendazole (Flu+Met+Thia); abamectin+thiametoxam (Aba+Thiam); abamectin+fludioxonil+metalaxyl$\mathrm{M}+$ thiabendazole (Aba+Flu+Met+Thia); thiamet hoxam+fludioxonil+metalaxyl-M+thiabendazole (Thiam+Flu+Met+Thia); and abamectin+thiamet hoxam+fludioxonil+metalaxyl-M+thiabendazole (Aba+Thiam+Flu+Met+Thia). Water was used as control for the in vitro assays, whereas under greenhouse conditions, controls were inoculated and not inoculated with $M$. javanica. The active ingredients (products), their respective doses and concentrations are described in Table 1.

Table 1. Description of the treatments with different active ingredients, commercial products and abbreviations used in the seed treatment tests for the control of Meloidogyne javanica under greenhouse and in vitro test conditions.

\begin{tabular}{|c|c|c|c|c|}
\hline & Treatments / Active ingredient & $\begin{array}{c}\text { Commercial product } \\
(\mathrm{CP})^{1} \\
\end{array}$ & Abbreviations & $\begin{array}{c}\text { Active } \\
\text { ingredient }\left(\mathrm{g} \mathrm{L}^{-1}\right)\end{array}$ \\
\hline 0 & Uninoculated control* & - & - & - \\
\hline 1 & Inoculated control & - & - & - \\
\hline 2 & Abamectin & Avicta ${ }^{\circledR}$ & Aba & 500 \\
\hline 3 & Thiamethoxam & Cruiser ${ }^{\circledR}$ & Thiam & 350 \\
\hline 4 & $\begin{array}{l}\text { Fludioxonil+Metalaxyl-M +Thia- } \\
\text { bendazole }\end{array}$ & Maxim Advanced ${ }^{\circledR}$ & Flu+Met+Thia & $25+20+150$ \\
\hline 5 & Abamectin+Thiamethoxam & Avicta $\AA+$ Cruiser $\AA$ & Aba+Thiam & $500+350$ \\
\hline 6 & $\begin{array}{l}\text { Abamectin + Fludioxonil+ Metalax- } \\
\text { yl-M+Thiabendazole }\end{array}$ & $\begin{array}{l}\text { Avicta }{ }^{\circledR}+\text { Maxim } \\
\text { Advanced } \AA\end{array}$ & $\begin{array}{c}\mathrm{Aba}+\mathrm{Flu}+\mathrm{Met}+ \\
\text { Thia }\end{array}$ & $500+25+20+150$ \\
\hline 7 & $\begin{array}{l}\text { Thiamethoxam+Fludioxonil }+ \\
\text { Metalaxyl-M+Thiabendazole }\end{array}$ & $\begin{array}{c}\text { Cruiser } \AA+\text { Maxim Ad- } \\
\text { vanced } \AA\end{array}$ & $\begin{array}{c}\text { Thiam+Flu+Met }+ \\
\text { Thia }\end{array}$ & $350+25+20+150$ \\
\hline 8 & $\begin{array}{l}\text { Abamectin+Thiamethoxam }+ \\
\text { Fludioxonil }+ \text { Metalaxyl-M }+ \text { Thia- } \\
\text { bendazole }\end{array}$ & Avicta Completo $®$ & $\begin{array}{c}\text { Aba+Thiam+Flu+ } \\
\text { Met }+ \text { Thia }\end{array}$ & $\begin{array}{c}500+350+25+ \\
20+150\end{array}$ \\
\hline
\end{tabular}

*Used only under greenhouse conditions

${ }^{1}$ Commercial Product Dose (100 mL of C.P. $100 \mathrm{~kg}^{-1}$ seeds). 
Obtaining the Meloidogyne javanica inoculum

The eggs of $M$. javanica were extracted from infested roots of tomato plants (Solanum lycopersicum L.) 'Santa Cruz,' grown in a greenhouse. The roots were washed and processed according to a method modified by Boneti and Ferraz (1981) in order to obtain the inoculum suspension, which was subjected to centrifugation after addition of $3 \mathrm{~g}$ of kaolin to eliminate root residues (COLLEN; D'HERDE, 1972). The suspension containing eggs and possible juveniles was quantified using Peters chamber placed under stereomicroscope, and stored for the hatch test.

To obtain juveniles of second stage (J2), for use in evaluating motility and mortality, a hatching chamber was set up with part of the previously obtained inoculum suspension. This suspension was deposited on filter paper, on sieves prepared on a Baermann funnel, filled with water to the level of the sieve mesh. The J2 were collected and quantified after $72 \mathrm{~h}$ using a Peters chamber placed under a microscope.

\section{Hatching of M. javanica juveniles in vitro}

The products studied (listed in Table 1) were diluted in water to obtain twice the concentrations indicated by the manufacturers. $1.0 \mathrm{~mL}$ aliquots of this dilution were deposited in test tubes containing $1.0 \mathrm{~mL}$ of the inoculum suspension with approximately 200 nematode eggs. In the control treatment, only water was added. The tubes were sealed and incubated at $26^{\circ} \mathrm{C}$ for 16 days under controlled conditions. The hatched $\mathrm{J} 2$ and the remaining eggs were quantified in the Peters chamber, and the percentage of hatching was calculated.

Motility and mortality of juveniles of $M$. javanica in vitro

Juveniles (J2) obtained in the hatching chamber were added to the test tubes along with a solution of the test products (active ingredients), as described above. In the control treatment, only water was added again. The $\mathrm{J} 2$ were incubated at $26^{\circ} \mathrm{C}$ under controlled conditions, and, after $24 \mathrm{~h}$, were washed and collected in a sieve (500 mesh). Using a Peters chamber placed under a microscope, the percentage of mobile and immobile juveniles was recorded to verify the effect of the products on nematode motility. Subsequently, the volume contained in the counting chamber was collected with a pipette and transferred to test tubes, where a $0.5 \% \mathrm{NaOH}$ solution was added according to the protocol proposed by Chen and Dickson (2000). After briefly shaking, this content was again transferred to the counting chamber for evaluating the number of mobile or immotile nematodes. The juveniles that were immobile after the addition of $\mathrm{NaOH}$ were considered dead, from which the motility percentage of M. javanica was calculated.

\section{Greenhouse tests}

Seeds of soybean 'BRS 133', susceptible to $M$. javanica and with 7.3 maturation cycle were used. Seed treatment was carried out in plastic bags in which the respective doses and concentrations of each product were added, sufficient to treat $0.7 \mathrm{Kg}$ of seeds. Subsequently, the seeds were homogenized until completely covered with the test products.

Part of the seeds was separated to evaluate the germination percentage using the filter paper test. The remaining seeds was placed in $3 \mathrm{~L}$ plastic containers filled with sand + soil (Eutroferric Red Latosol) in a 2:1 $\left(\mathrm{v} \mathrm{V}^{-1}\right)$ ratio, sterilized in an autoclave at $120^{\circ} \mathrm{C}$ for $2 \mathrm{~h}$. Three seeds per container were used, and seven days after sowing thinning was performed before inoculation to maintain one plant per container during the study.

The nematode inoculum was extracted from infested roots of tomato plants 'Santa Cruz,' according to the method described (BONETI; FERRAZ, 1981). Each plant was inoculated with 5000 eggs and possible juveniles of $M$. javanica contained in $5 \mathrm{~mL}$ of suspension. 
The plants were evaluated at 15,30 and 60 days after inoculation (DAI). At 15 DAI, the following parameters were also evaluated: fresh root mass and shoot length. The entry of juveniles into the root system was also evaluated by staining the nematodes with acid fuchsin (BYRD JUNIOR et al., 1983).

At 30 and 60 DAI, the plants were evaluated for fresh root mass, shoot length, number of egg masses (EM), galls, final population $(\mathrm{FP}=\operatorname{eggs}+\mathrm{J} 2)$, and the number of nematodes per gram of root (FP/fresh root mass) was recorded.

Figure 1. Hatching percentage (A), immobilization (B) and mortality (C) of juveniles of Meloidogyne javanica evaluated in vitro, after exposure to the active ingredients.

A

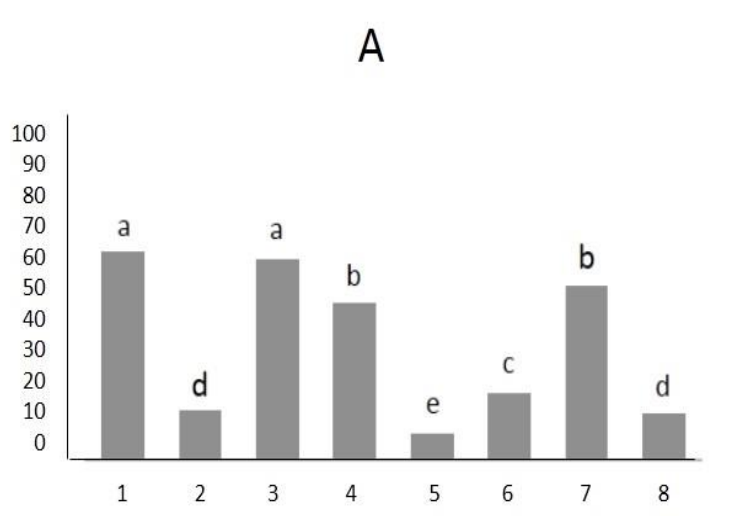

C

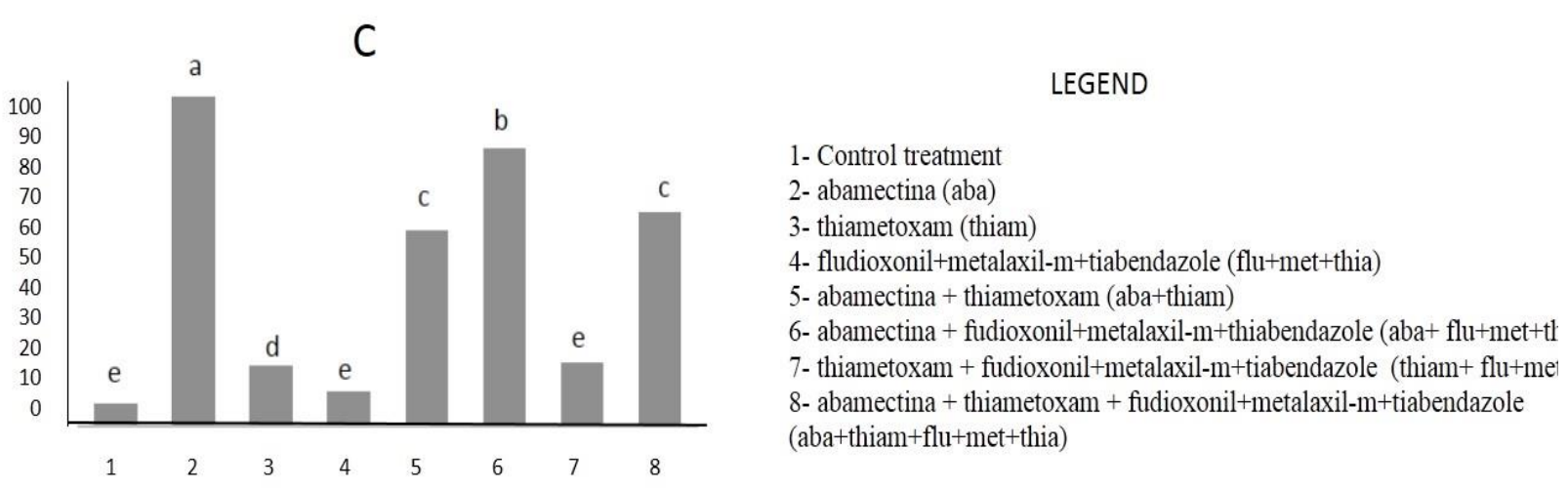

After analysis of the normality using the ShapiroWilk test and homogeneity of variances (F-test), when necessary, the data were transformed to $\sqrt{ }(\mathrm{x}+$ 0.5 ) and subjected to analysis of variance (ANOVA) and Scott-Knott test at 5\% significance levels, using the SISVAR software.

\section{Results and Discussion}

All treatments containing abamectin, either isolated or in combination with the other active ingredients reduced hatching and motility, but increased M. javanica J2 mortality (Figure 1).

\section{In vitro tests}

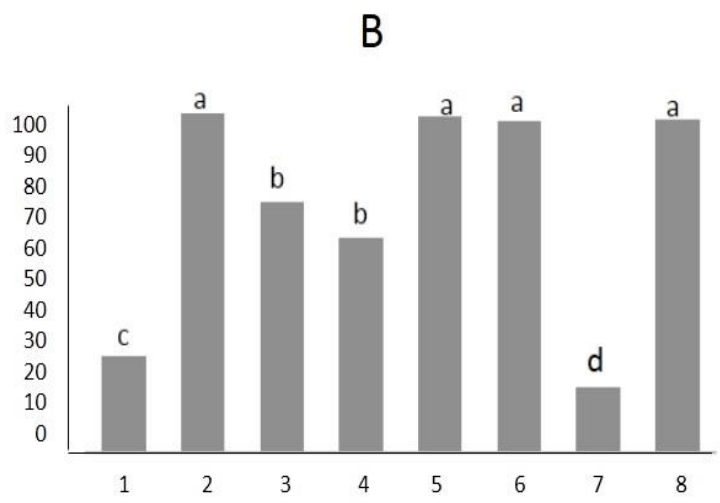

Treatment 5 (Aba+Thiam) resulted in a 8 (Aba+Thiam+Flu+Met+Thia), 2 (Aba) and 6 lower percentage of hatching of M. javanica J2, (Aba+Flu+Met+Thia), which were 13.73, 14.97 and with a value of $7.81 \%$, followed by treatments 19.86 hatch percentages, respectively, and differing 
statistically from the control with $62.17 \%$ hatch percentage. The other treatments were less efficient, although they differed statistically from the control, had a higher percentage of hatching with $47.18 \%$ for treatment 4 (Met+Flu+Thia) and $52.26 \%$ for treatment 7 (Thiam+Flu+Met+Thia). The exception was the treatment 3 (Thiam), which did not differ from the control with $59.9 \%$ hatching.

When examining the J2 motility results, it was found that the treatments containing abamectin (Treatments 2 - Aba; 5 Aba+Thiam; 6 - Aba+Me+Flu+Thia and 8 Aba+Thiam+Met+Flu+Thia) had over 95\% of immobile J2, and had no differ between these treatments. Treatments 3 (Thiam) and 4 (Met+Flu+Thia) also had a significant effect on nematode motility, and differed from the control.

For mortality study, only in the treatment 2 (Aba) containing abamectin alone, there was no nematode recovery resulting in a $99 \%$ mortality rate. In the remaining combinations containing abamectin, a partial recovery of the motility of $\mathrm{J} 2$ was observed, with the treatments 6 (Aba+Met+Flu+Thia), 8 (Aba+Thiam+Met+Flu+Thia) and 5 (Aba+Thiam) having $83.87 \%, 64.61 \%$ and $59.3 \%$ of mortality, respectively, and differing from the control that had $6.67 \%$ of $\mathrm{J} 2$ mortality after addition of sodium hydroxide. Treatments 4 (Met+Flu+Thia) and 7 (Thiam+Met+Flu+Thia) also had low J2 mortality similar to the control.

According to Wright et al. (1983), the effect of avermectin on the behavior of M. incognita juveniles is three-phased and depends on the time of exposure to the product. When exposed for $10 \mathrm{~min}$, they lose movement, but remain sensitive to touch. After a 30 min exposure, there is a partial recovery of these nematodes, and after 120 minutes, the paralysis is irreversible, and corroborating our results, where after exposure to abamectin no recovery in nematode motility was observed. It has been reported that even low concentrations of abamectin are sufficient to cause irreversible paralysis of $M$. incognita and $R$. reniformis just after 1-hour exposure to abamectin, relative to their respective lethal doses 50 (FASKE; STARR, 2007).

Avermectins, such as abamectin, exhibit a different mode of action when compared to organophosphate and organocarbamate nematicides. These are antagonists of gamma-aminobutyric acid (GABA), interfering with neuronal impulses leading to irreversible paralysis and death of the nematode (REDDY, 2013). The high mortality of M.javanica juveniles observed in our results is consistent with the aforementioned report. In this case, in addition to the nematostatic effect, abamectin was the only chemical possessing nematicidal effect. The other actives studied also had an effect on $M$. javanica; for instance, Thiamethoxam, an insecticide classified as an acetylcholine (ACh) antagonist has an analogous effect to this excitatory neurotransmitter and competes with it for its receptors. In insects, in the early stages of exposure to the product, hyperexcitability of the nervous system occurs, which causes loss of muscle coordination, seizures and subsequent death due to respiratory failure. In insects, these occur in the ganglia of the central nervous system because there is no ACh in the peripheral nervous system (GUEDES; VILELA, 1991). Thiabendazole, on the other hand, was used as an anthelmintic in human medicine and was introduced to agriculture in 1964. It has a broad spectrum of antifungal activity similar to thiophanate-methyl, being routinely used in seed treatment (KIMATI, 2011). The mechanism of action of both thiabendazole and thiamethoxam against nematodes is not fully elucidated. However, research has indicated the reduction in phytonematodes population in plants of seeds previously treated with these active compounds (FAVORETTO et al., 2010; KUBO et al., 2012; RIBEIRO et al., 2012).

\section{Tests under greenhouse conditions}

The active ingredients used in the seed treatment did not affect seed germination, which varied from 85 to $95 \%$, and no difference between the treatments was observed (data not presented). 
At 15 DAI, statistical differences between the treatments for the number of nematodes per gram of root (Nem/gRoot), fresh root mass (FRM), and shoot length measurement (SLM) existed (Table 2). In this first evaluation, it was clear that the treatments influenced the reduction of the initial population of $M$. javanica in the roots. With the exception of treatment 5 (Flu+Met+Thia), the other treatments significantly reduced the number of Nem/gRoot compared to the inoculated and untreated control (Table 2). As for the development of the plants, treatments 6 (Aba+Thiam), 8 (Thiam+Flu+Met+Thia) and 9 (Aba+Thiam+Flu+Met+Thia) allowed for increased root development (FRM), differing from the inoculated control and even higher than the non-inoculated control. Plants with a better developed root system are more known to be efficient in absorbing water and nutrients. Thus, the treatments with higher values for fresh root mass also had higher average values for shoot length measurement (SLM), similar to the non-inoculated nematode control (Table 2). Steffen et al. (2011), also observed that the treatments with abamectin resulted in higher averages for height, dry shoot mass and root length in rice plants. However, Kubo et al. (2012) did not observe such differences for plant height, dry shoot mass and dry mass of roots as a function of the treatment of cotton seeds. The differences observed between the two studies may be due to variations in response to treatments by the plant, or influenced by the plant characteristics themselves, or by the differences in the evaluation period, cultivars, and nematode species studied. The results of the evaluations performed at $30 \mathrm{DAI}$ are shown in Table 3. For fresh root mass (FRM), no difference between treatments was observed. However, the seed treatment with these active ingredients resulted in averages for shoot length measurement (SLM) that were significantly higher than the control plants. The products used in seed treatments generally have a protective function during the initial stage of crop development, particularly against pests and diseases. However, they can also offer physiological and developmental benefits to plants. Thiamethoxam, besides being a systemic insecticide of the neonicotinoid group, has a bioactive effect and influences the expression of genes responsible for the synthesis and activation of metabolic enzymes related to plant growth (CASTRO, 2006).

Table 2. Number of nematodes per gram of root (Nem/gRoot), fresh root mass (FRM) and shoot length measurement (SLM) of soybean plants 'BRS 133' from seeds treated with different active ingredients, evaluated at 15 days after inoculation with Meloidogyne javanica.

\begin{tabular}{lccc}
\hline Treatments / Active ingredient & Nem/gRoot & FRM (g) & SLM (cm) \\
\hline 0 - Uninoculated control & - & $3.28 \mathrm{~b}$ & $23.12 \mathrm{a}$ \\
1 - Inoculated control & $81.74^{1} \mathrm{a}^{2}$ & $1.89 \mathrm{c}$ & $13.58 \mathrm{c}$ \\
2 - Aba & $45.23 \mathrm{~b}$ & $2.33 \mathrm{c}$ & $14.60 \mathrm{~b}$ \\
3 - Thiam & $60.59 \mathrm{~b}$ & $2.23 \mathrm{c}$ & $15.44 \mathrm{~b}$ \\
4 - Flu+Met+Thia & $79.18 \mathrm{a}$ & $2.37 \mathrm{c}$ & $16.04 \mathrm{~b}$ \\
5 - Aba+Thiam & $42.36 \mathrm{~b}$ & $4.33 \mathrm{a}$ & $22.18 \mathrm{a}$ \\
6 - Aba+Flu+Met+Thia & $49.98 \mathrm{~b}$ & $3.32 \mathrm{~b}$ & $18.52 \mathrm{~b}$ \\
7 - Thiam+Flu+Met+Thia & $48.63 \mathrm{~b}$ & $4.05 \mathrm{a}$ & $21.96 \mathrm{a}$ \\
8 - Aba+Thiam+Flu+Met+Thia & $36.06 \mathrm{~b}$ & $4.76 \mathrm{a}$ & $25.24 \mathrm{a}$ \\
CV \% & 26.97 & 19.43 & 17.55 \\
\hline
\end{tabular}

${ }^{1}$ Original averages of 10 replicates transformed to $\sqrt{ }(x+0.5)$.

${ }^{2}$ Averages followed by the same letters do not differ significantly in Scott-Knott's test $(\mathrm{P}=0.05)$. 
Regarding the effect of treatments on the reproduction of $M$. javanica in the roots, at 30 DAI (Table 3), the results were variable depending on the analyzed variable. For the number of galls, treatments 3 (Aba), 7 (Aba+Flu+Met+Thia) and 9 (Aba+Thiam+Flu+Met+Thia) had the lowest value. As for egg masses, in addition to the treatments that reduced the number of galls, treatment 6 (Aba+Thiam) was also efficient, showing a common effect in all the treatments containing abamectin in that they had a lower egg mass compared to the control. The results were similar for final population (FP), and the number of nematodes per gram of root (Nem/gRoot), indicating that the efficiency of treatments 3 (Aba), 4 (Thiam), 6 (Aba+Thiam), 7 (Aba+Flu+Met+Thia) and 9 (Aba+Thiam+Flu+Met+Thia) in reducing the population of $M$. javanica in the roots (Table $3)$. The effect of abamectin through seed treatment on the M. javanica population was also verified by Corte et al. (2014), but the authors infer that the efficiency and sensitivity of the active ingredients on the populations of Meloidogyne spp. and Heterodera spp. were primarily due to their feeding habits. This is likely because these nematodes tend to form permanent feeding sites in the roots, thereby increasing the probability of coming into contact with the active ingredients. However, it is known that abamectin acts externally to the seed and is considered to provide initial protection from nematode attack in the seedlings (AGROFIT, 2017).

Table 3. Vegetative development of soybean plants 'BRS 133', from seeds treated with different active ingredients and population of Meloidogyne javanica at 30 days of inoculation.

\begin{tabular}{|c|c|c|c|c|c|c|c|c|c|}
\hline Treatments & FRM * & SLM * & Galls & & $\mathbf{E M}^{*}$ & & $\mathbf{F P}^{*}$ & & Nem/gRoot ${ }^{*}$ \\
\hline 1 - Uninoculated control & $22.49^{1} \quad \mathrm{a}^{2}$ & $56.73 \mathrm{~b}$ & - & & - & & - & & - \\
\hline 2 - Inoculated control & $19.36 \mathrm{a}$ & $61.22 \mathrm{~b}$ & 239.1 & $\mathrm{a}$ & 180.2 & $\mathrm{a}$ & 18187.7 & $\mathrm{a}$ & $1126.5 \mathrm{a}$ \\
\hline $3-\mathrm{Aba}$ & $23.11 \mathrm{a}$ & $68.10 \mathrm{a}$ & 130.6 & $\mathrm{~b}$ & 98.0 & b & 6678.5 & $b$ & $341.1 \mathrm{~b}$ \\
\hline 4 - Thiam & $18.12 \mathrm{a}$ & $66.01 \mathrm{a}$ & 222.3 & $\mathrm{a}$ & 141.6 & $\mathrm{a}$ & 13621.0 & b & $801.2 \mathrm{~b}$ \\
\hline $5-$ Flu+Met+Thia & $21.41 \mathrm{a}$ & $67.72 \mathrm{a}$ & 243.9 & $\mathrm{a}$ & 168.2 & $\mathrm{a}$ & 28862.0 & $\mathrm{a}$ & 1455.9 a \\
\hline 6-Aba+Thiam & $14.31 \mathrm{a}$ & $70.10 \mathrm{a}$ & 318.2 & $\mathrm{a}$ & 106.3 & $\mathrm{~b}$ & 11418.1 & b & $835.5 \mathrm{~b}$ \\
\hline $7-$ Aba+Flu+Met+Thia & 17.82 a & $66.92 \mathrm{a}$ & 153.6 & $\mathrm{~b}$ & 109.6 & $\mathrm{~b}$ & 13177.1 & $\mathrm{~b}$ & $1089.4 \mathrm{~b}$ \\
\hline $8-$ Thiam+Flu+Met+Thia & $18.70 \mathrm{a}$ & $65.80 \mathrm{a}$ & 239.1 & $\mathrm{a}$ & 164.8 & $\mathrm{a}$ & 25119.5 & $\mathrm{a}$ & $1475.1 \quad \mathrm{a}$ \\
\hline 9 - Aba+Thiam+Flu+Met+Thia & $19.09 \mathrm{a}$ & $67.31 \mathrm{a}$ & 106.7 & $\mathrm{~b}$ & 84.0 & $\mathrm{~b}$ & 10039.7 & b & $648.3 \mathrm{~b}$ \\
\hline $\mathrm{CV} \%$ & 20.53 & 9.95 & 47.4 & & 30.99 & & 31.9 & & 38.37 \\
\hline
\end{tabular}

${ }^{*} \mathrm{FRM}=$ fresh root mass; SLM= shoot length measurement; $\mathrm{EM}=$ egg mass; FP= final population; Nem/gRoot= Number of nematodes per gram of root.

${ }^{1}$ Original averages of 10 replicates transformed to $\sqrt{ }(x+0.5)$.

${ }^{2}$ Averages followed by equal letters do not differ significantly in Scott-Knott's test $(\mathrm{P}=0.05)$.

Table 4 shows the results of the evaluations performed at $60 \mathrm{DAI}$, where it was possible to observe that treatments 4 (Thiam) and 5 (Flu+Met+Thia) resulted in fresh root mass (FRM) similar to the inoculated control, but higher than the other treatments. Regarding plant height, there was no significant differences between the treatments.

In relation to the final population (FP) of $M$. javanica, it was confirmed that the treatments containing abamectin (3-Aba; 6-Aba+Thiam; 7 $\mathrm{Aba}+$ Flu+Met+Thia and 9-Met+Thia) had average values similar to the inoculated and untreated control, but lower than the other treatments (Table 4). These results were expected, because high activity of the products applied in seed treatment occurs in the initial stages of the culture. Corte et al. (2014), for example, observed a reduction in the control level at 90 days after emergence (DAE) 
compared to $30 \mathrm{DAE}$, due to loss of efficacy or residual effect of the active ingredients with the development of the culture. Faske and Starr (2007) also explained that abamectin is concentrated in the seed tegument, and as the roots develop beyond this protective region, they are exposed to nematode attack. Moreover, seed treatment promotes greater root system development, which becomes a very efficient nutritional source for nematodes, resulting in increased nematode populations at the end of the crop cycle (BESSI et al., 2010).

Table 4. Fresh root mass (FRM), shoot length measurement (SLM), and final population (FP) of Meloidogyne javanica in soybean plants 'BRS 133', from seeds treated with different active ingredients evaluated at 60 days after inoculation.

\begin{tabular}{lcccc}
\hline Treatments & FRM(g) & SLM (cm) & FP $^{*}$ \\
\hline 1 - Uninoculated control & $58.0^{1} \mathrm{~b}^{2}$ & $76.3 \mathrm{a}$ & - & \\
2 - Inoculated control & $72.2 \mathrm{a}$ & $73.3 \mathrm{a}$ & $209160 \mathrm{c}$ \\
3 - Aba & $50.2 \mathrm{~b}$ & $73.8 \mathrm{a}$ & $198407 \mathrm{c}$ \\
4 - Thiam & $90.7 \mathrm{a}$ & $82.7 \mathrm{a}$ & $333200 \mathrm{~b}$ \\
5 - Flu+Met+Thia & $75.8 \mathrm{a}$ & $81.2 \mathrm{a}$ & $386390 \mathrm{~b}$ \\
6 - Aba+Thiam & $61.8 \mathrm{~b}$ & $79.9 \mathrm{a}$ & $264480 \mathrm{c}$ \\
7 - Aba+Flu+Met+Thia & $56.0 \mathrm{~b}$ & $78.3 \mathrm{a}$ & $278820 \mathrm{c}$ \\
8 - Thiam+Flu+Met+Thia & $55.6 \mathrm{~b}$ & $78.1 \mathrm{a}$ & $456400 \mathrm{a}$ \\
9 - Aba+Thiam+Flu+Met+Thia & $50.2 \mathrm{~b}$ & $69.6 \mathrm{a}$ & $293447 \mathrm{c}$ \\
CV \% & 34.9 & 8.58 & 32.19 \\
\hline
\end{tabular}

${ }^{*} \mathrm{FP}=$ final population.

${ }^{1}$ Original averages of 10 replicates transformed to $\sqrt{ }(x+0.5)$.

${ }^{2}$ Averages followed by equal letters do not differ significantly in Scott-Knott's test $(\mathrm{P}=0.05)$.

However, the control of the nematode population in the initial phase of the crop is fundamental to ensure protection and realization of the yield potential of the crop (OLIVEIRA et al., 1999; GALBIERI et al., 2007).

The duration of protection provided by the seed treatment can also be enhanced by improving the mode of application, in addition to combining with other types of products. Homiak et al. (2017) achieved successful control of $P$. brachyurus in soybean grown under greenhouse conditions by combining an inducer of resistance to the seed treatment. Cabrera et al. (2009), suggest that the amount of nematicides applied in the furrow can also be reduced with the use of abamectin in the seed treatment. The study of polymers that enhance the persistence of contact of the active ingredient with the plant and/or that slows the degradation of the nematicide may contribute to improved control.
Seed treatment and application techniques should be improved, especially with the improvement of industrial treatment (MENTEN; MORAES, 2010), which has been acting as a facilitator in the management of nematodes and other pathogens, especially in large crops such as soybean. The results obtained here show that the products used in the treatments for soybean seeds of 'BRS 133' can be used as a complementary tool in the management of $M$.javanica, to maintain adequate population and a good crop stand.

\section{Conclusions}

In vitro, isolated abamectin, or in combination with the other active ingredients reduced hatching, motility and led to high mortality of $M$. javanica juveniles. 
In greenhouse conditions, the soybean seeds of 'BRS 133' treatment was effective in controlling $M$. javanica until 30 days after inoculation (DAI);

At 15 DAI, except for treatment 5 (Flu+Met+Thia), all the treatments reduced the $M$. javanica population in the roots, in comparison to the inoculated and untreated control;

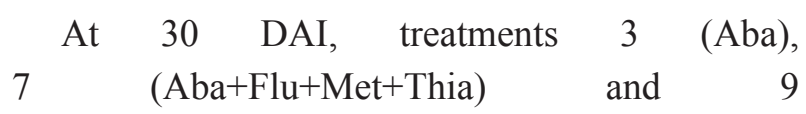

(Aba+Thiam+Flu+Met+Thia) reduced the number of galls in the roots. All treatments containing abamectin were effective in reducing the egg mass value. For the final population, and the number of nematodes per gram of root, treatments 3 (Aba), 4 (Thiam), 6 (Aba+Thiam), and 7 (Aba+Flu+Met+Thia) were efficient and reduced the $M$. javanica population in the roots.

The results obtained here show that the products studied for the treatment of soybean seeds 'BRS 133' may be used as a complementary approach in the management of $M$.javanica, helping in maintaining reduced nematode populations in crop fields.

\section{Acknowledgments}

We thank the Coordination for the Improvement of Higher Education Personnel (Capes) for granting the scholarship to the first author

\section{References}

BESSI, R.; SUJIMOTO, F. R.; INOMOTO, M. M. Seed treatment affects Meloidogyne incognita penetration, colonization and reproduction on cotton. Ciência Rural, Santa Maria, v. 40, n. 6, p. 1428-1430, 2010.

BONETI, J. I. S.; FERRAZ, S. Modificações do método de Hussey e Barker para a extração de ovos de Melodogyne exigua, em raízes de cafeeiro. Fitopatologia Brasileira, Porto Alegre, v. 6, p. 553, 1981. Suplemento.

BYRD JUNIOR, D. W.; KIRKPATRICK, T.; BARKER, K. R. An improved technique for clearing and staining plant tissues for detection of nematodes. Journal of Nematology, Gainesville, v. 15, n. 1, p. 142-143, 1983.
CABRERA, J. A.; KIEWNCK, S.; GRIMM, C.; DABABAT, A. A.; SIKORA, R. A. Efficacy of abamectin seed treatment on Pratylenchus zeae, Meloidogyne incognita and Heterodera schachtii. Journal of Plant Diseases and Protection, Berlin, v. 116, n. 3, p. 124-128, 2009.

CASTRO, P. R. C. Bioativador estimula produção de hormônios responsáveis pelo crescimento da soja. São Paulo: Agência USP de Notícias, 2006. Disponível em: $<$ http://www.usp.br/agen/repgs/2006/pags/169.htm>. Acesso em: 29 ago. 2006.

CHEN, S. Y.; DICKSON, D. W. A technique for determining live second-stage juveniles of Heterodera glycines. Journal of Nematology, Gainesville, v. 32, n. 1, p. 117-121, 2000.

COMPANHIA NACIONAL DE ABASTECIMENTO - CONAB. $10^{\circ}$ Levantamento - Safra 2016/2017 - Grãos. Brasília: CONAB, 2017. Disponível em: $<$ http://http://www.conab.gov.br/OlalaCMS/uploads/ arquivos/17_07_12_11_17_01_boletim_graos_ julho_2017.pdf $>$. Acesso em: 10 ago. 2017.

COOLEN, W. A.; D'HERDE, C. J. A method for the quantitative extraction of nematodes from plant tissue. Ghente: State Agricultural Research Centre, GHENT, $1972.77 \mathrm{p}$.

CORTE, G. D.; PINTO, F. F.; STEFANELLO, M. T.; GULART, C.; RAMOS, J. P.; BALARDIN, R. S. Application technology of pesticides for control of soybean nematodes. Ciência Rural, Santa Maria, v. 44, n. 9, p. 1534-1540, 2014.

FASKE, T. R.; STARR, J. L. Cotton root protection from plant parasitic nematodes by abamectin-treated seed. Journal of Nematology, Gainesville, v. 39, n. 1, p. 27-30, 2007.

FAVORETTO, L.; SANTOS, J. M.; CALZAVARA, S. A.; BARBOSA, J. C.; LARA, L. A. Estudo do processo de infecção de sementes de Brachiaria brizantha por espécies de Aphelenchoides e de tratamentos para o controle desses nematoides. Nematologia Brasileira, Piracicaba, v. 34, n. 1, p. 10-17, 2010.

FOOD AND AGRICULTURE ORGANIZATION OF THE UNITED NATIONS - FAO. FAOSTAT, Food and agricultural commodities production. Roma: FAOSTAT, 2016. Available at: <http://faostat3.fao.org/ browse/Q/ QC/E>. Accessed at: 23 nov. 2016.

GALBIERI, R.; MACHADO, A. C. Z.; CIA, E.; LÜDES, R. R.; CARVALHO, L. H.; MOTTA, L. C. C. Comparação entre nematicida e cultivares no controle de nematoides em algodoeiro. Fitopatologia Brasileira, Brasília, v. 32, p. 128-129, 2007. Suplemento. 
GUEDES, R. N. C.; VILELA, E. F. Produtos que agem na fisiologia dos insetos. In: VILELA, E. F. (Ed.). Novos produtos para o manejo integrado de pragas. Brasília: ABEAS, 1991. p. 59-70. (Módulo 4.7).

HOMIAK, J. A.; DIAS-ARIEIRA, C. R.; COUTO, E. A. A.; KATH, J.; ABE, V. H. F. Seed treatments associated with resistance inducers for management of Pratylenchus brachyurus in soybean. Phytoparasitica, North Andover, v. 45, n. 2, p. 243-250, 2017.

INOMOTO, M. M.; ASMUS, G. L. Controle de nematoides une resistência, rotação e nematicidas. Visão Agrícola, Piracicaba, v. 6, n. 2, p. 47-50, 2006.

KIMATI, H. Controle químico. In: AMORIM, L.; REZENDES, J. A. M.; GERGAMIM FILHO, A. Manual de fitopatologia. 4. ed. Piracicaba: Agronômica Ceres, 2011. p. 343-365.

KUBO, R. K.; MACHADO, A. C. Z.; OLIVEIRA, C. M. G. Efeito do tratamento de sementes no controle de Rotylenchulus reniformis em dois cultivares de algodão. Arquivos do Instituto Biológico, Campinas, v. 79, n. 2, p. 239-245, 2012.

MENTEN, J. O.; MORAES, M. H. D. Tratamento de sementes: histórico, tipos, características e benefícios. Informativo Abrates, Piracicaba, v. 20, n. 3, p. 52-53, 2010.

MOENS, M.; PERRY, R. N.; STAR, J. L. Meloidogyne species - a diverse group of novel and important plant parasites. In: MOENS, M.; PERRY, R. N.; STAR, J. L. (Ed.). Root-knot nematodes. Wallingford: CABI International, 2010. p. 1-13.

MONFORT, W. S.; KIRKPATRICK, T. L.; LONG, D. L.; RIDEOUT, S. Efficacy of a novel nematicidal seed against Meloidogyne incognita on cotton. Journal of Nematology, Gainesville, v. 38, n. 2, p. 245-249, 2006.

MOREIRA, W. A.; BARBOSA, F. R.; MAGALHÃES, E. E.; MENEZES, C. F.; PEREIRA, A. D. S. Aplicação de abamectina como alternativa de controle químico do nematoide-das-galhas em melão. In: CONGRESSO BRASILEIRO E FRUTICULTURA, 18., 2004, Florianópolis. Anais... Florianópolis: SBF: Governo do Estado: Epagri, 2004. CD-ROM.
OLIVEIRA, C. M. G.; KUBO, R. K.; SILOTO, R. C.; RAGA, A. Eficiência de carbofuran e terbufós sobre nematoides e pragas iniciais na cultura algodoeira. Revista de Agricultura, Piracicaba, v. 74, n. 3, p. 325344, 1999.

REDDY, P. P. Recent advances in crop protection. New Delhi: Ed. Springer India Heielberg Dordrecht London, 2013. 268 p.

RIBEIRO, L. M.; CAMPOS, H. D.; RIBEIRO, G. C.; NEVES, D. L.; DIAS-ARIEIRA, C. R. Efeito do tratamento de sementes de algodão na dinâmica populacional de Pratylenchus brachyurus em condições de estresse hídrico. Nematropica, Gainesville, v. 42, n. 1, p. 84-90, 2012.

SISTEMAS DE AGROTÓXICOS FITOSSANITÁRIOS - AGROFIT. Brasília: Ministério da Agricultura, Pecuária e Abastecimento - Coordenação-Geral de Agrotóxicos e Afins/DFIA/DAS, 2017. Disponível em: <http://agrofit. agricultura.gov.br/agrofit_cons/principal_agrofit_cons $>$. Acesso em: 30 jul. 2017.

STARR, J. L.; KOENNING, S. R.; KIRKPATRICK, T. L.; ROBINSON, A. F.; ROBERTS, P. A.; NICHOLS, R. L. The future of nematode management in cotton. Journal of Nematology, Gainesville, v. 39, n. 4, p. 283294, 2007.

STEFFEN, R. B.; ANTONIOLLI, Z. I.; STFFEN, G. P. K.; JACQUES, R. J. S.; ECHKARDT, D. P. Efeito da Abamectina e carbofuran no controle de danos causados por Meloidogyne graminicola em plantas de arroz irrigado. Revista da FZVA, Uruguaiana, v. 18, n. 2, p. 56$69,2011$.

WRIGHT, D. J.; LOY, A.; GREEN, A.; DYBAS, R. A. The translaminar activity of abamectin (MK-936) against mites and aphids. Mededelingen van de Faculteit Landbouwwetenschappen Rijksuniversiteit, Gent, v. 50, n. 2, p. 595-601, 1983. 
